\title{
Toward A Multidimensional Model Of Social Entrepreneurship: Definitions, Clarifications, And Theoretical Perspectives
}

Andrea E. Smith-Hunter, Siena College

\begin{abstract}
A number of significant research projects have explored various aspects of social entrepreneurship, some demonstrating that, given an appropriate level of focus, social entrepreneurship is a viable area for research that can be studied and explored like its counterpart and predecessor, general entrepreneurship. This paper offers a true definition of social entrepreneurship by relating it to three key measures from general entrepreneurship: human capital, network structure, and financial capital. The current status of social entrepreneurship is also examined and summarized.
\end{abstract}

Keywords: Entrepreneurship, Social Entrepreneurship, Prosocial Behavior

\section{INTRODUCTION}

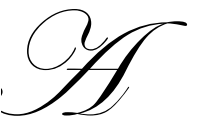

number of significant research projects have demonstrated that given an appropriate level of focus, social entrepreneurship is a viable area for research that can be studied and explored like its counterpart and predecessor- general entrepreneurship. The quantifiable success of social entrepreneurs in established transitional and struggling economies has been reported in recent years, as well as the tremendous impact social entrepreneurs now have on economic, social, and societal structures. The field of social entrepreneurship is therefore well-positioned to take its place in the area of business entrepreneurship, and related areas of economics and sociology.

On practical and theoretical levels, social entrepreneurship has seen monumental strides taken in the last decade because of its additional entrenchment in the world of not-for-profit organizations and volunteerism. This is not a passing fad, but is a new paradigm whose conceptual and theoretical roots are taking hold in the field of general entrepreneurship, and the reason for the focus on this field.

Various aspects of social entrepreneurship have been explored, (Drayton, Brown and Hillhouse, 2006; Donovan, 2002; Christie and Honig, 2006; Peberdy and Rogerson, 2000; Singer, 2001; Linklaters, 2006; Lasprogata and Cotton, 2003), some focusing on the meaning of social entrepreneurship and its influence on the wider sphere of entrepreneurial research (Donovan, 2002; Singer, 2001; Lasprogata and Cotton, 2003), others emphasizing the vast number of existing social entrepreneurs or entrepreneurship projects (Drayton, Brown and Hillhouse, 2006; Christie and Honig, 2006; Peberdy and Rogerson, 2000; Linklaters, 2006).

Christie and Honig (2006), Peberdy and Rogerson (2000), and Singer (2001) have researched the role of social entrepreneurship in developing and developed countries, Linklaters (2006), and Lasprogata and Cotton (2003) have studied the financial obligations, laws, and regulations regarding social entrepreneurship in various parts of the world. Sharir and Lerner (2005) have postulated that the factors leading to success for social entrepreneurs are no different from the factors that have led to success for traditional entrepreneurs.

According to Mair and Marti (2006), exploration of social entrepreneurship provides a unique opportunity to challenge, question, and rethink concepts and assumptions from different fields of management and business 
research. Mair and Marti further suggest that while entrepreneurship in its early days was a field of scholarly endeavor, social entrepreneurship is still largely phenomenon-driven. They believe that the current boundaries of social entrepreneurship are still poorly defined, with fuzzy research parameters, and further state that other researchers in the field see the lack of definitive barriers as an opportunity to borrow from related fields such as sociology, organizational behavior, management, and, of course, traditional entrepreneurship (Mair and Marti, 2006).

Weerwardena and Mort (2006) studied the definitions of social entrepreneurship offered by twenty different studies. Emphasized were the differences in perspective and focus of the definitions in the varying domains they occupy. Consistent with research in the early days in traditional entrepreneurship, in social entrepreneurship the definition of the subject matter will need to be applied in such a way as to yield consistent results.

This paper departs from that trend by stepping back and reassessing the true definition and meaning of social entrepreneurs and the impending implications. Three key measures from general entrepreneurship are also discussed: human capital, network structure, and financial capital, and how these measures apply to the area of social entrepreneurship. The current status of social entrepreneurship is described, including critical issues, research parameters, and recommendations for future focus on social entrepreneurship.

By analyzing and building on current research in general entrepreneurship and social entrepreneurship, this paper elucidates some of the key elements of social entrepreneurship for a better understanding of the definitions related to the field. A new working definition of social entrepreneurship is also proposed.

\section{DEFINITIONS}

\section{Business/Traditional Entrepreneurship}

The term "entrepreneur" is traditionally defined as "a person who starts or organizes a commercial enterprise, especially one involving financial risk" (Peredo and McLean, 2006). Bygrave and Hofer (1991), and Gartner (1989) define an entrepreneur as "an individual who perceives an opportunity and partakes in the necessary functions, activities, and actions associated with the creation of an organization to pursue that opportunity."

These definitions apply to two other entrepreneurial areas - the business owner and the self employed. The Small Business Act states that "a small business concern shall be deemed to be one which is independently owned and operated and which is not dominant in its operation" (U.S. Small Business Administration, 1978). A small business owner is defined as the person who owns such a business entity, or "as an individual who has a financial capital investment in a business that is greater than $\$ 0$ and annual sales/revenue of at least $\$ 1000 "$ (Bates, 1995a; Devine, 1994a; 1994b).

Carland, Hoy, Bolton and Carland (1984) define a small business owner as "an individual who establishes and manages a business for the principal purpose of furthering personal goals. The business must be the primary source of income and will consume the majority of one's time and resources." The owner perceives the business as an extension of his or her personality and is intricately bound with family needs and desires.

"Self-employment" is defined literally as being employed by oneself (Steinmetz and Wright, 1989), and indicates that one is working for oneself in any job that is held longest during a particular year, in either an incorporated or unincorporated business (Devine, 1994a).

\section{Social Entrepreneurship}

Social entrepreneurship means different things to different people, including researchers and individuals. Schwab (2006) defines a social entrepreneur as "someone who has created and led an organization whether for profit or not, that is aimed at catalyzing systematic social change through new ideas, products, services, methodologies and changes in attitude, with the bottom line being social value creation." 
Bornstein (2004) defines social entrepreneurs as "people who recognize social problems, then use traditional entrepreneurial principles to organize, create and manage ventures to facilitate social change." Social entrepreneurs are thus identified as "people who recognize and relentlessly pursue opportunities to create social value" (Bornstein, 2004). According to Barendsen and Gartner (2004), social entrepreneurs "approach social problems with entrepreneurial spirit and business acumen." Bornstein (2004) states that social entrepreneurs "combine the savvy, opportunism, optimism and resourcefulness of business entrepreneurs, with the devotion and pursuit of 'social profit,' rather than business profit."

While the language of social entrepreneurship may be new, the field itself is not. Social entrepreneurs have always existed, even if not labeled as such. William Lloyd Garrison, who founded the Anti-Slavery Society in 1833, Jane Addams, a social worker and reformist who founded the social settlement, Hull House in Chicago in 1889, and Susan B. Anthony, also known as "the biblical Moses," have all been referred to as social entrepreneurs (Barendsen and Gartner, 2004).

Korosec and Berman (2006) define social entrepreneurs as "individuals or private organizations that take the initiative to identify and address important social problems in their communities." Their focus is on the initial stages of developing new programs, and includes specific activities such as raising awareness, identifying and acquiring resources, coordinating actions with other agencies, and setting up programs in ways that are consistent with modern management strategies.

Lasprogata and Cotten (2001) compare social entrepreneurs with not-for-profit entrepreneurs, concluding that social entrepreneurs "are individuals who recognize and relentlessly pursue new opportunities that serve their mission." They also state that non entrepreneurs are engaged in earned income strategies that bring in additional revenue to support their mission and that they apply these strategies to sustain themselves financially, while having a greater mission for their social cause (Lasprogata and Cotton, 2001). They are both said to engage in a process of continuous innovation, adaptation, and learning (Lasprogata and Cotton, 2001). They act boldly with limited resources on hand, exhibiting a heightened sense of accountability to the constituencies served and for the outcomes created (Lasprogata and Cotton, 2001). The authors see the two as being synonymous with each other, especially regarding the purposes of their existence.

Mair and Martin (2004) consider social entrepreneurs and two closely related fields: social entrepreneurship and social enterprise. Taking definitions from various sources, they contend that social entrepreneurship is a system that creates innovative solutions to social problems (Mair and Martin, 2004). Social entrepreneurs are defined as the change agents in social entrepreneurship systems, and social enterprises are defined as private organizations dedicated to solving social problems (Mair and Martin, 2004).

The majority of other researchers define social entrepreneurs by focusing on the establishment of new enterprises or the continued innovation of existing enterprises to fulfill social needs (Thompson, Alvy and Lees, 2000; Anderson, Dana and Dana, 2006). According to Thompson (2002), social entrepreneurs are also said to have the qualities and behaviors generally associated with business entrepreneurs, but they operate in communities and are more concerned with caring and helping, than with making money, thus helping to change people's lives as they embrace important social causes.

Bornstein (2004) states that a social entrepreneur has both a powerful idea to cause a positive social change and the creativity, skills, determination, and drive to transform that idea into reality. Social entrepreneurs combine the savvy, opportunism, optimism, and resourcefulness of business entrepreneurs, but they devote themselves to pursuing social change or social profit rather than financial profit. They pursue business profit with the idea that social profit is a subset of business profit. Peredo and Mclean (2006) add that social entrepreneurship thus features social goals as one of its outcomes.

Dees (1998) insists that any definition of social entrepreneurship should reflect the need for a substitute for the market discipline that works for business entrepreneurs. Dees further points out that social entrepreneurs are change agents in the social sector, in that they: 
- $\quad$ adopt missions to create and sustain social value (not just private value);

- $\quad$ recognize and relentlessly pursue new opportunities to serve that mission;

- $\quad$ engage in a process of continuous innovation, adaptation, and learning;

- $\quad$ act boldly without being limited by resources currently in hand; and

- $\quad$ exhibit heightened accountability to the constituencies served and for the outcomes created.

Seelos and Mair ( 2005) state that, like business entrepreneurs, social entrepreneurs recognize and act upon opportunities to improve systems, create solutions, and invent new approaches. Citing Venkataraman (1997), they state that the study of traditional entrepreneurship shows that social wealth is a byproduct of economic values created by the traditional entrepreneurs. In contrast, in the field of social entrepreneurship, social value creation is a primary objective, while economic value creation is often a byproduct that allows the organization to achieve sustainability and self-sufficiency. For social entrepreneurs, economic value creation - in the sense of being able to capture part of the created value in financial terms - is often limited, mainly because the "customers" that social entrepreneurs serve may be willing but unable to pay for even a small part of the products and services provided.

The term "social entrepreneur" has been inadvertently substituted and purported to be synonymous with four other related entrepreneurial terms: political entrepreneurs, policy entrepreneurs, public entrepreneurs, and civic entrepreneurs. These terms are closely related, but are not the same.

Korosec and Berman (2006) have also inadvertently attempted to make the terms "social entrepreneurs" and "civic entrepreneurs" synonymous. However, the terms have different meanings. They describe civic entrepreneurs as private individuals and organizations, who take the initiative to address social challenges in their communities, and state that social entrepreneurs study the generation of profit and address social issues as criteria for the operation of the enterprise, with both being of equal importance.

A public entrepreneur creates or profoundly elaborates on a public organization, so as to alter greatly the existing pattern of allocation of scarce public resources (Waddock and Post, 1991).

Roberts and King (1991) define public entrepreneurship as the process of introducing innovation-the generation, translation, and implementation of new ideas-into the public sector, describing them also as policy entrepreneurs in the same vein as public entrepreneurs, who from outside the formal positions of government introduce, translate, and help implement new ideas into public practice.

Roper and Cheney (2005) link social entrepreneurship to the public-sector area, which is said to overwhelmingly stress rational economic calculations and links to market data from the entrepreneurial world, through alignment with public agencies.

Policy entrepreneurs and public entrepreneurs are terms that are also often used interchangeably. King and Roberts (1992) offer the best synchronization of these terms: public entrepreneurs generate creative policy solutions, redesign government programs, and implement new management approaches to revitalize the public sector. Hemingway (2005) adds that policy entrepreneurs consistently actualize their power in a collaborative manner, while working with others rather than employing coercive tactics to overpower them.

A policy entrepreneur uses a formalized agenda in pursuit of social initiatives, such as health care reform (Hemingway, 2005) or income support reform. Hemingway further points out that the difference between social and policy entrepreneurship may be the levels of power each hold in the business. Social entrepreneurs are likely to be the driving force that follows through, once the policy entrepreneur has derived the policy and it has been agreed upon by the relevant parties.

Policy entrepreneurs, as defined by Mintrom (1997a and 19977b), seek to initiate dynamic policy change by attempting to win support for their ideas for policy innovation. They use several activities to promote their agenda, such as identifying problems, networking in policy circles, shaping the terms of policy debates, and building coalitions. 
Political entrepreneurs on the other hand, state Schneider and Teske (1992) address issues related to political profits affected by the extent of entry barriers and the strategic use of information, challenges to entrepreneurs rooted in collective action problems, and the dynamic effect of entrepreneurs on political equilibrium. The premise is that political entrepreneurs are tied to a variety of theoretical issues, such as the opportunity or potential opportunity for profit in the political arenas and in the communities that nurture the creation of politicallyinstigated entrepreneurial ventures.

Roper and Cheney (2005) describe various categories-or a range or continuum-of social entrepreneurship. They state that in private social entrepreneurship, chief executive officers and leaders in nonpublicly-held companies have great freedom to pursue their cherished values, creating an intersection of planning, profit, and innovation. They further discuss the obvious coexistence of social entrepreneurship and the not-for-profit sectors, such as social movement organizations, social advocacy groups, and community initiatives, as being natural progressions, based on the common goals of both sectors. There is a certain blurring of the objectives of social entrepreneurship and not-for-profit sectors which allow for a mutual co-existence.

In summary, social entrepreneurship definitions can vary enormously according to what is covered by each definition, but seem to agree that a social entrepreneur:

- $\quad$ recognizes and takes the initiative to address social problems, using traditional entrepreneurial principles to organize, create, and manage a venture to make a social change (Korosec and Berman, 2006);

- $\quad$ is involved in the establishment of new enterprises or the continued innovation of existing enterprises to fulfill social needs (Thompson, Alvy, and Lees, 2000; Anderson, Dana, and Dana, 2006), and has qualities and behaviors associated with business entrepreneurs, but who operates in the community and is more concerned with caring and helping, than with making money, helping to change people's lives as they embrace important social causes (Thompson, 2002); and

- $\quad$ combines the savvy, opportunism, optimism, and resourcefulness of business entrepreneurs, but is devoted to pursuing social change or social profit rather than financial profit (Bornstein, 2004).

Thus, while social entrepreneurs pursue business profit, they do so with the understanding that social profit is also pursued as a subset of business profit. Thus, social entrepreneurship features social welfare as one of its goals (Peredo and Mclean, 2006).

\section{Business Entrepreneurship compared to Social Entrepreneurship}

A comparison between "social entrepreneurship" and the traditional/business term "entrepreneurship," or what is sometimes referred to in the literature as commercial entrepreneurship, is helpful in the context of finding an accurate definition. Peredo and McLean (2006) suggest that there is a "continuum of social goals," or ranges, to social entrepreneurship. This continuum, they state, is marked by the prominence of social goals and the salient features of entrepreneurship. Social entrepreneurship organizations, as opposed to not-for-profits and social organizations, has five key components that:

- aim either exclusively or in some prominent way to create social value, and pursue that goal through some combination ;

- $\quad$ recognize and exploit opportunities to create value;

- $\quad$ employ innovative techniques;

- $\quad$ tolerate risk; and

- $\quad$ decline to accept limitations in available resources.

Austin, Stevenson, and Wei-Skillern (2006) echo the sentiments of Peredo and McLean (2006), offering definitions of social entrepreneurship that range from narrow to broad perspectives. In the narrow definition, social entrepreneurship typically means applying business enterprise and market-based skills in the not-for-profit sector, developing innovative approaches to earn income (Austin, Stevenson, and Wei-Skillern, 2006). The broader definition is one of innovative, social, and value-creating activity that can occur within or across the not-for-profit, 
business, or government sectors (Austin, Stevenson, and Wei-Skillern, 2006). The distinction between social and commercial/business/traditional entrepreneurship is not dichotomous, but rather more accurately conceptualized as a range from purely social to purely economic (Austin, Stevenson, and Wei-Skillern, 2006). The four key components used to distinguish between social and commercial entrepreneurship are: mission, resource mobilization, market failure, and performance (Austin, Stevenson, and Wei-Skillern, 2006).

Dees (2001) states that for social entrepreneurs, the mission is explicit and central. This affects how social entrepreneurs perceive and assess opportunities. This mission-related impact becomes the central criterion, as opposed to that of wealth in social entrepreneurship. Wealth is seen as just a means to an end for social entrepreneurs. In contrast, business entrepreneurs view wealth as a way of measuring value creation. This is because business entrepreneurs are subject to market discipline, which determines whether they are creating value, while the social entrepreneur is assessed on ability to create social value

Boschee and McLurg, (2003) contend that the social entrepreneur also differs from the traditional/business/commercial entrepreneur in two additional ways:

- Traditional entrepreneurs may donate money to not-for-profits, but their efforts are only indirectly attached to social problems. Social entrepreneurs differ in that their earned income strategies are tied directly to their mission.

- Traditional entrepreneurs are ultimately measured by financial results. In contrast, social entrepreneurs are driven by a double bottom line, a blend of financial and social returns.

Winfield (2005), and Sagawa and Segal (2000) also contend that both business and social entrepreneurship emphasize innovation and change. Sagawa and Segal state that social entrepreneurship differs from business entrepreneurship in that the former sets out with an explicit social mission in mind, making the world a better place to create value, whereas business entrepreneurship does not (Winfield, 2005).

\section{LITERATURE REVIEWS}

\section{Overview}

Social entrepreneurship theory is still in the infancy stage of conceptualization. Research to date exhibits the uncertainty that is often attached to a project or paradigm that lacks full development. Early studies focus on the philanthropic elements of social entrepreneurship (Dees, 2005; Jain, 2004; Singer, 2001; Thompson and Doherty, 2006; Backer, 2004), emphasizing the social mission aspect. Others describe social entrepreneurship as a major trend in the world of business (Bornstein, 2994), identifying and glorifying the individuals active in the field, such as Harvey Kostenberg (who works with the Diabetes Foundation), Farouk Jovia (founder of Honey Care in Kenya which revitalized that nation's honey industry) and Gib Myers (creator of Entrepreneur's Foundation which encourages businesses to pledge donations to charitable events at their start-up stages), cited in Munday (2003), Osborne (2001) and African Business (2004).

While venture philanthropy has generated a lot of interest and has added to the focus on social entrepreneurship, the literature in this area is also not succinct in that it lacks the focus needed to develop into a viable area of research. Two notable articles identify the laws, regulations, and financial obligations of corporations or individuals who engage in social entrepreneurship (Leibell, Daniels and Rickerhauser, 2006; Linklaters, 2006). Linklater presents findings in a report that studies the relevant laws and regulations in six countries: Brazil, Germany, India, Poland, United Kingdom, and the United States of America. While Leibel et al (2006) looked at the legal implications of foundations operating as social entrepreneurs.

Some studies focus on impact and the development, particularly of a social nature, in the geographic areas in which the studies were conducted. Nafziger (1977), for example, examines the caste system in India and criticizes the role of entrepreneurship as a force for redistributing wealth as an unrecognized myth. Nafziger (1977) concluded that rather than being a path for social mobility and income distribution, entrepreneurship and the resulting industrial 
growth that occurred in this sector has led to a perpetuation of vast disparity, and thus an affluence gap between the haves and the have nots (Nafziger, 1977). The author also alludes to the position that entrepreneurship could hold if it served a business as well as a social component.

While a study by Mizrachi (1994) focuses on the impact of entrepreneurs on other sectors of a nation's economy - the political sector as well as the economic sector.

Seelos and Mair (2005) focus on the intersection of social responsibilities and corporate goals and, thus, business strategies and entrepreneurial ventures. They indicate that social entrepreneurship, with its point of departure from business entrepreneurship, creates new models for the provision of products and services that cater directly to basic human needs unsatisfied by current economic or social institutions. They state that the traditional area of business entrepreneurship focuses on the creation of financial wealth, with social wealth creation occurring as a byproduct. In social entrepreneurship the reverse is true; social value creation is a primary focus, whereas economic or financial value creation is a byproduct necessary for sustainability and continuity of the venture.

Anderson, Dana, and Dana (2006) explore Canadian business development activities by aboriginal groups with claims of indigenous rights to land and resources, suggesting that the process is an aspect of social entrepreneurship. They contend that the approach is an instance of social entrepreneurship that create opportunities - and businesses - for funding social objectives. A key focus for the various groups is the search for, and identification of, suitable opportunities to satisfy communitywide objectives.

This social movement with economic gains is akin to the partnership of several socioeconomic factors that was explored by Breton and Breton in a 1969 study. They contend that the structural components of the environment and the structural alliance of social movements with other environmental factors-whether of a political or economic nature-is necessary for the sustainability of entrepreneurial ventures (Breton and Breton, 1969).

One sector of the literature focuses on the individuals who engage in social entrepreneurship, seeking to identify common denominators that characterize them and lead to their success. Sharir and Lerner (2006) focus on the process of initiating, establishing, and institutionalizing thirty-three social entrepreneurs in the 1990s, individuals who have acted independent of their positions in other organizations. They name eight variables that contribute to the success of the social value:

- $\quad$ the entrepreneur's social network;

- $\quad$ total dedication to the venture's success;

- $\quad$ the capital base at the establishment stage;

- $\quad$ the acceptance of the venture idea in the public discourse;

- $\quad$ the composition of the venturing team, including the ratio of volunteers to salaried employees;

- $\quad$ forming of corporations in the public and not-for-profit sectors in the long term;

- $\quad$ the ability of the service to stand the market test; and

- $\quad$ the entrepreneur's previous managerial experience.

Thompson, Aloy, and Lees (2000) believe that other researchers are needed as catalysts to study social entrepreneurship, and contend that social entrepreneurs provide new opportunities and create additional benefits for social reasons. In addition, this unique brand of entrepreneurship also needs the "right people," champions who are willing to volunteer their services and time, who are adequately skilled, qualified, and appropriately trained, in order to enhance, rather than inhibit the social initiatives. This conclusion is reinforced by Hemingway in a 2005 study that contends that morality, personal values, and entrepreneurial talents are needed to form a vortex of socially responsible behavior in order to produce sustainable benefits (Hemingway, 2005).

Koresec and Berman (2006) examine municipal support for social entrepreneurship and how cities assist social entrepreneurs in achieving goals. Their study examines jurisdictions with populations of over 50,000 residents and found that the clout offered by government municipalities can increase the level of awareness of problems faced by social entrepreneurs (Koresec and Berman, 2006). As a result of the increased visibility, they are able to acquire, 
coordinate, and distribute resources (Koresec and Berman, 2006). Approximately 75 percent of the municipalities provided moderate or active support for social entrepreneurs who in turn had a positive impact on the type of programs implemented, as well as on their level of effectiveness (Koresec and Berman, 2006).

Christie and Honig (2006) posit that social entrepreneurs are an important "invisible hand" that can assist economies, because recent research has shown increasingly that nongovernmental organizations (NGOs), nonprofit organizations (NPOs), entrepreneurial firms, governments, and public agencies are needed in developing and developed countries to assist and sustain such economies. Seeing social entrepreneurs as change agents that can create and sustain social value without government or other policy restrictions is an important first step in understanding the value created by social entrepreneurs.

In a 2006 study, Weerawardena and Mort use grounded theory to draw on more in-depth case studies of social entrepreneurial not-for-profit organizations. The study identifies key areas where strategy and operations can be aligned in social entrepreneurial service contexts. The authors recommend that social entrepreneurial organizations adopt a culture aimed at innovativeness, proactiveness, and risk management (Weerawardena and Mort, 2006). They also recommend development of decision-making techniques based on dynamic programming to improve proactive management of the environmental context (Weerawardena and Mort, 2006). They conclude that social entrepreneurial organizations must address value positioning strategies, and take a proactive posture and provide superior service that maximizes social value creation (Weerawardena and Mort, 2006).

If the theory of social entrepreneurship is to develop into a mature stage, more research needs to tie this relatively new form to the traditional theory of entrepreneurship and thus the business world

\section{Human Capital Literature}

A first step in linking areas of traditional entrepreneurship to social entrepreneurship can begin with issues of human capital. The section which follows looks at the literature related to the human capital aspect of entrepreneurship.

Based on the definition of entrepreneurship offered in this paper, it is obvious that the individual, as a focus, is the core of, and thus the very essence of what an entrepreneur is. With that in mind, any study of entrepreneurship, absent a specific type of entrepreneurial venture with such factors as gender, race, and geographic location of business - requires the individual to be a critical focus of any research in this area (Shaver and Scott, 1991; Stearns and Hill, 1996; Gartner, 1985). An integral part of the focus on the individual is an evaluation of the definitions and dimensions of the term "human capital." The term was originally used by Nobel economist Gary Becker (1964), to refer to the stored value of knowledge or skills of members of the workforce. The consensus among scholars is that human capital is critical to the formation and performance of entrepreneurial ventures.

Human capital is thus defined by Becker (1993) as "the propensity of a person or group to perform behavior that is valued from an income earning perspective by an organization or a society."

Human capital also encompasses the knowledge, skills, competencies, and attributes of individuals that facilitate the creation of personal, social, and economic wellbeing. This definition extends beyond those capital assets linked directly to productivity and encompasses factors that reflect the broader values associated with a welleducated population (Becker, 1993). The term "human capital" has traditionally been applied to educational attainment and includes the knowledge and skills that the labor force accumulates through formal instruction, training, and experience. Heckman (2000) states that the term has also been used to encompass the time, experience, knowledge, and abilities of an individual household or a generation, which can be used in the production process. This definition relates to the income earning potential of individuals as workers in the mainstream labor market or the field of entrepreneurship.

A number of studies examined the dimensions that encompass the growth of an individual's human capital potential. The studies range from educational attainment to work experience (Beggs, 1995; Raymn and Xie, 2000; 
Gimeno, Folta, Cooper and Woo, 1997; Godoy, O’Neill, McSweeney and Wilkie, 2000; Gartner and Bhat, 2000) and include issues such as knowledge of the dominant language in the geographic region (Sanders and Nee, 1996; Pendakur and Pendakur, 2002) and the impact of parents' educational levels and background (Farkas, England, Vicknair and Kilbourne, 1997; Bates, 1990; Hendricks, 2001; Guiaitoli, 2000). Other dimensions examined are additional sources of learning such as that obtained from contact with friends and associates (Heckman, 2000; Boucekkine, de la Croix and Licandro, 2002). In specific reference to entrepreneurs, some authors believe that having parents who were themselves entrepreneurs increases the human capital measure and also increases the chances for an individual to become an entrepreneur (Cooper and Dunkelberg, 1987).

The literature consistently indicates that an increase in the percentage of human capital as individual possesses has a positive impact on, and thus denotes a positive relationship with, one's income earning potential (Evans and Leighton, 1989; Greller and Stroh, 2002; Godoy et al, 2000), and that differences in human capital are a key factor that results in labor market inequalities for various groups (Beggs, 1995). Others research presents human capital as an intangible asset, with skills such as educational levels, knowledge, and experience that can be used for economic gains (Christou, 2001; Cianni and Romberger, 1995). Boyd's study (1996) points out that the undervaluing of disadvantaged groups' human capital potential, in particular those of minorities, has caused them to reap fewer rewards in terms of their income earning potential when compared to their other entrepreneurial counterparts. This argument was echoed by Kazemipur and Halli (2001) who researched immigrants in Canada using census data, and found that human capital factors were of less importance to immigrants than to natives.

These dimensions of human capital can also be applied to and take root in a discussion on social entrepreneurship. The issues related to education level, experience, training, and skills that are applicable to the traditional entrepreneur are likewise relevant and necessary for social entrepreneurs (see Figure 1).

\section{Network Structure Literature}

A second step in linking areas of traditional entrepreneurship to social entrepreneurship can begin with issues of human capital. The section which follows looks at the literature related to the network structure aspect of entrepreneurship.

Studies by Putnam (1995) and Henry (2002) indicate that our social connections and civic engagements pervasively influence our public life as well as our private prospects. These social bonds are essential to a group's success, and a substantial stock of social trust is said to make life easier for participants in their community. Nowhere is this concept and its resulting implications more critical than in the area of entrepreneurship. A number of studies have exalted the importance of the connections of entrepreneurs to others who can influence their progress (Wilkinson and Young, 2002; Hyden, 2001; Loscocco et al, 1991; Gassenheimer, Baucus and Baucus, 1996).

Network structures can be defined as the formal and informal connections of overlapping organizational, family, and social memberships that account for our level of success, and the resources we have available to us to satisfy our needs, obligations, and expectations (Hogan, 2001; Easter, 1996; Aldrich, Reese and Dubini, 1989; Coughlin and Thomas, 2002). It has also been described as the "hidden hand of influence" that impacts the development of business markets (Hogan, 2001; Choi and Hong, 2002; Chung and Gibbons, 1997). The theory has its roots in the sociological world of social capital, defined by Hogan (2001) as the weaving of interpersonal relationships and values within families and their communities. Chung and Gibbons (1987) consider that information exchange and learning takes place in network structures and involves the ways in which an individual is related to others in their families and communities (Fukuyama, 2002; Van Horn and Harvey, 1998). It is also depends on a person's ability to communicate and cooperate in a group setting and is determined by three key group influences: work, family, and social life, according to Aldrich, Reese, and Dubini (1989). Bailey and Waldinger (1991) and Low and Macmillan (1988) state that network structure can be of a formal nature (banks, lawyers, business organizations) as well as an informal nature (family, friends, associates).

The key factor that makes entrepreneurs' network structures so critical to their development and success is access to additional network structures. In essence, not only are entrepreneurs connected formally and informally 
through relationships with other individuals and sectors, but, depending on the type of relationship, the potential exists for each of these individuals in the entrepreneur's "primary" network structure to in turn provide access to their own network structures, allowing the entrepreneur access to a "secondary" network structure.

Figure 2 shows how friends, workplace affiliations, and government agencies represent the primary network structures, while the dots at the end of the links, which connect to these primary structures, represent individuals or organizations in one's secondary network structure. This can lead to a level of interconnected relationships for entrepreneurs through indirect sources (Lucas et al., 2001). The strength of each network link is dependent on the amount of assistance provided to the entrepreneurs through these links. Therefore, there are strong or weak network links depending on what type of access is available and what resources they are in turn linked to (Lucas et al., 2001; Fratoe, 1986; Low and Macmillan, 1988; Feagin and Imani, 1994).

It is important for individuals to seek, through coordinated efforts, groups of other individuals for their locus of support, instead of operating in a vacuum. The dimension of one's network structure is said to include family, friends, religious and work affiliations, banks, lending agencies, government agencies, and associates. These connections in turn provide role models, training experiences, advice, financial support, sources of labor, clientele, business advice, and contracts for market shares (Fratoe, 1986; Molm, Peterson and Takahashi, 2001). Knowing the role of weak or strong social networks is particularly important for understanding how individuals are steered to opportunities and vice versa (Mier and Giloth, 1986).

Network structures and their application in the traditional entrepreneurship sector and its dimensions can also be useful in a discussion about social entrepreneurship, since its dimensions are also applicable: issues related to accessing and developing a primary and secondary network structure.

\section{Financial Capital Literature}

There remains a definitive link between one's access to financial capital and the economic success of their business (Finnerty and Krzystofik, 1986). While there are different ways to measure financial success for business owners (Begley and Boyd, 1987), studies have repeatedly shown that access to financial capital at the start-up stage and during the operation of a business is a key determinant to the expansion, sustainability, and consistency of its existence (Ong, 1981; Terpstra and Olson, 1993; O’Hare and Suggs, 1986). Possible sources of financial capital include, but are not limited to: liquid assets (checking and saving accounts), credit lines, loans, capital leases (mortgages and motor vehicle loans), financial management services (transaction and cash management), owner loans, credit cards, and trade credits (Bitler, Robb and Wolken, 2001).

As noted, financial capital is one of the key ingredients that enable businesses to expand, remain viable, and become sustainable with long term goals. While a comprehensive criticism of all the factors impacting the financial status of all groups of entrepreneurs is outside the realm of this paper, it is necessary to invoke a framework for understanding and evaluating the importance of financial sustainability to all group of entrepreneurs - both social and traditional business entrepreneurs.

Based on the findings of the described research on financial capital and its application in the traditional entrepreneurship sector, its dimensions can also be applied to, and take root in, a discussion on social entrepreneurship. In addition, a model for success for traditional entrepreneurs will need some modification in order to derive an appropriate model of success for social entrepreneurship. Figure 3 shows a model of success for traditional entrepreneurs. This model looks at issues such as human capital, network structures, and financial capital, as being relevant for success. However, in the case of social entrepreneurship, success has two dimensions attached to it (see Figure 4): the financial/economic success (taken from the traditional area of entrepreneurship, and social success (interpreted to mean the impact on the social strata of the relevant economy). 


\section{SUMMARY AND CONCLUSIONS}

This paper provided a number of critical observations. First, the concept and parameters of social entrepreneurship are not in conflict with the assumptions originally proposed by Schumpeterian theory for a traditional entrepreneur. The two topics can thus coexist in the entrepreneurial world. The traditional view of entrepreneurship centers on an individual who is an innovator and a dynamic economic operator. Those qualities are still necessary for social entrepreneurs, navigating in their sector.

Second, a new model is offered for defining entrepreneurial success. In traditional entrepreneurship the assumption is that the human capital, network structures, and access to financial capital of the entrepreneurs lead to success for the entrepreneurial venture, but the same is not true for the definition of success in the world of social entrepreneurship (see Figures 3 and 4). In the field of social entrepreneurship, success has been described as a "double bottom-line"-success that is measured both financially and by the impact on the social strata and environment where the social entrepreneur has chosen to explore or invest in and channel resources. Some of the same strategies, processes, and programs are needed in both sectors, including the mutual cooperation of entrepreneurs and other individuals such as venture capitalists (Cable and Shane, 1997), in order to achieve financial/economic success, a necessity in both cases for maintaining a sustainable existence.

Third, the social entrepreneurship framework adds an important dimension that is also an extension of the current model of traditional entrepreneurship. Thus, the existing model of entrepreneurship is still relevant in the area of social entrepreneurship. The latter can be viewed as a specialized subsystem with an added density and depth that requires more in the area of structural variations in the path to success.

In analyzing the relevant areas in the social entrepreneurship literature, a number of divergent definitions have provided narrow and broad definitions. A definitive meaning is fundamental to a follow up discussion on various elements of social entrepreneurship, since the definition frames the discussion that ensues.

The impact of social entrepreneurship, and even more so business entrepreneurship, is critical to any country, since both are often engaged in sectors abandoned or left delinquent by the formal structure of an economy. Social entrepreneurship thus serves as a viable alternative to the lack of a structured system of government, to assist those most in need of help that comes through unorthodox means and creative and innovative ways of thinking. 
Figure 1: Model of Human Capital Dimensions for Entrepreneurs

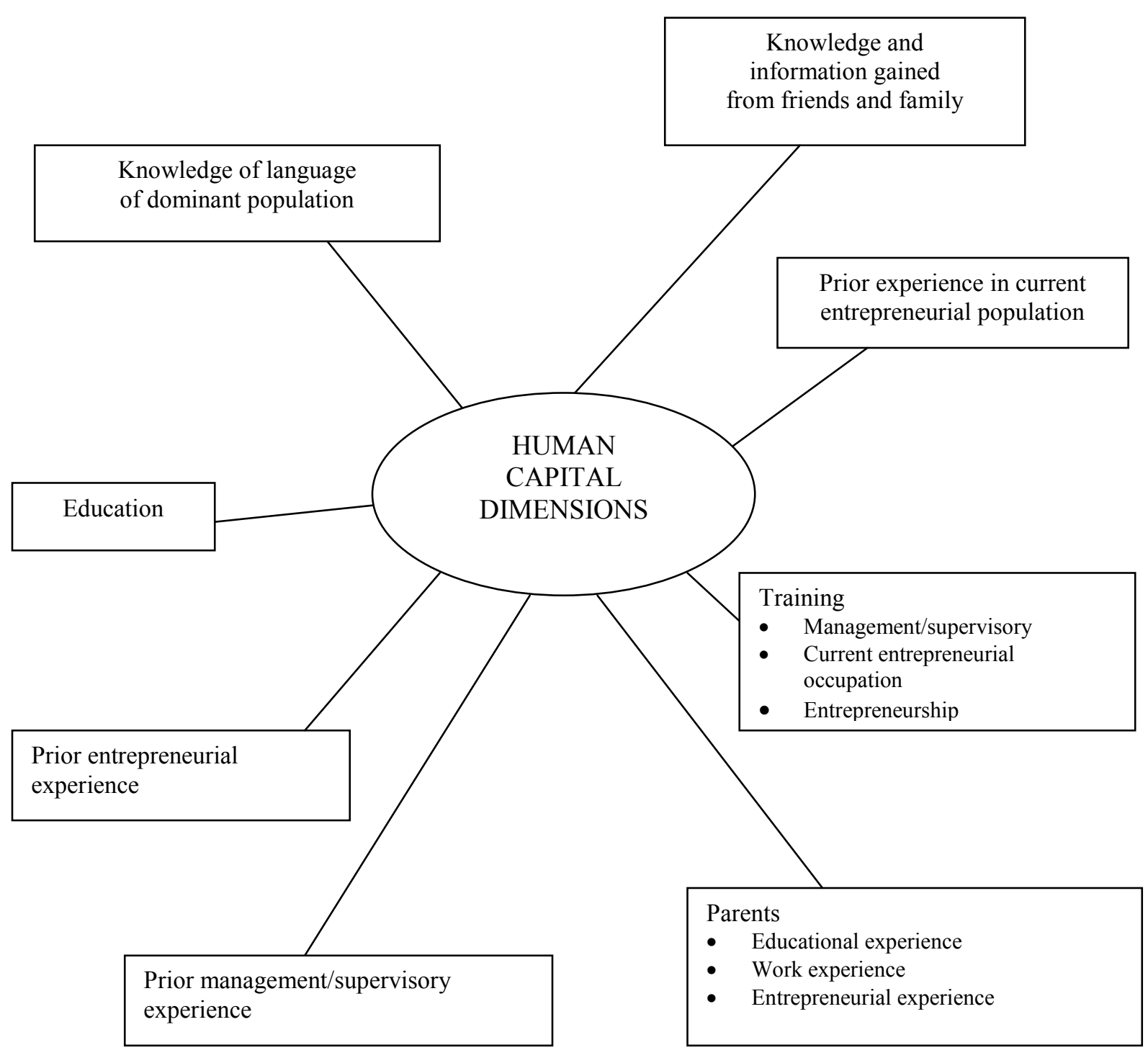


Figure 2: Model of Network Structures of Entrepreneurs

Informal Influences

a) Family
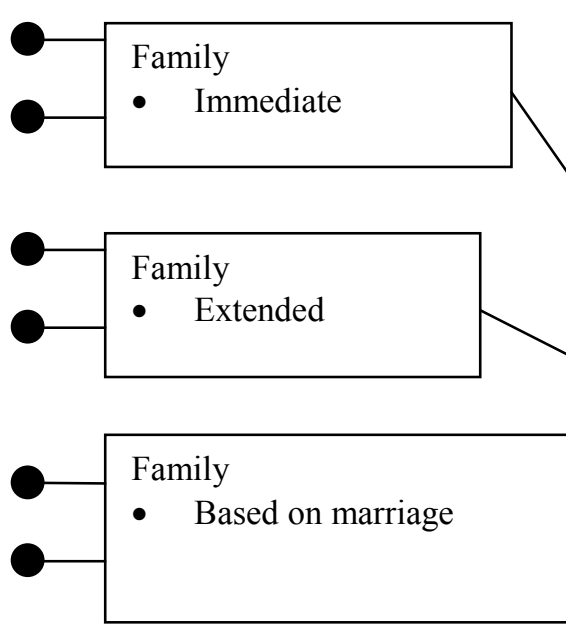

b)

Social Influences

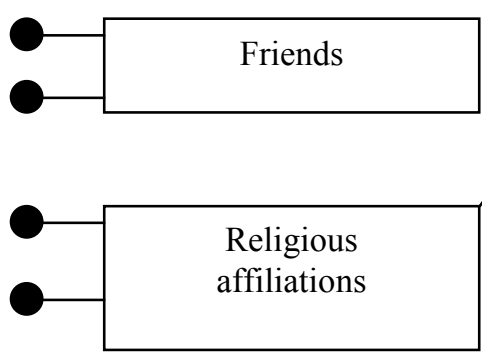

Clubs, societies, and other membership organizations
Formal Influences

Business membership in organizations

- General

Business

membership in

organizations

- Industry specific

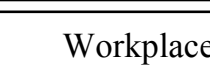

affiliations

Banks and lending agencies
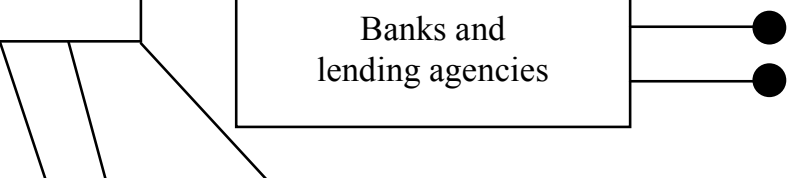

Educational organizations

(

Training organizations 
Figure 3: Model of Entrepreneurial Success (Traditional Entrepreneur)

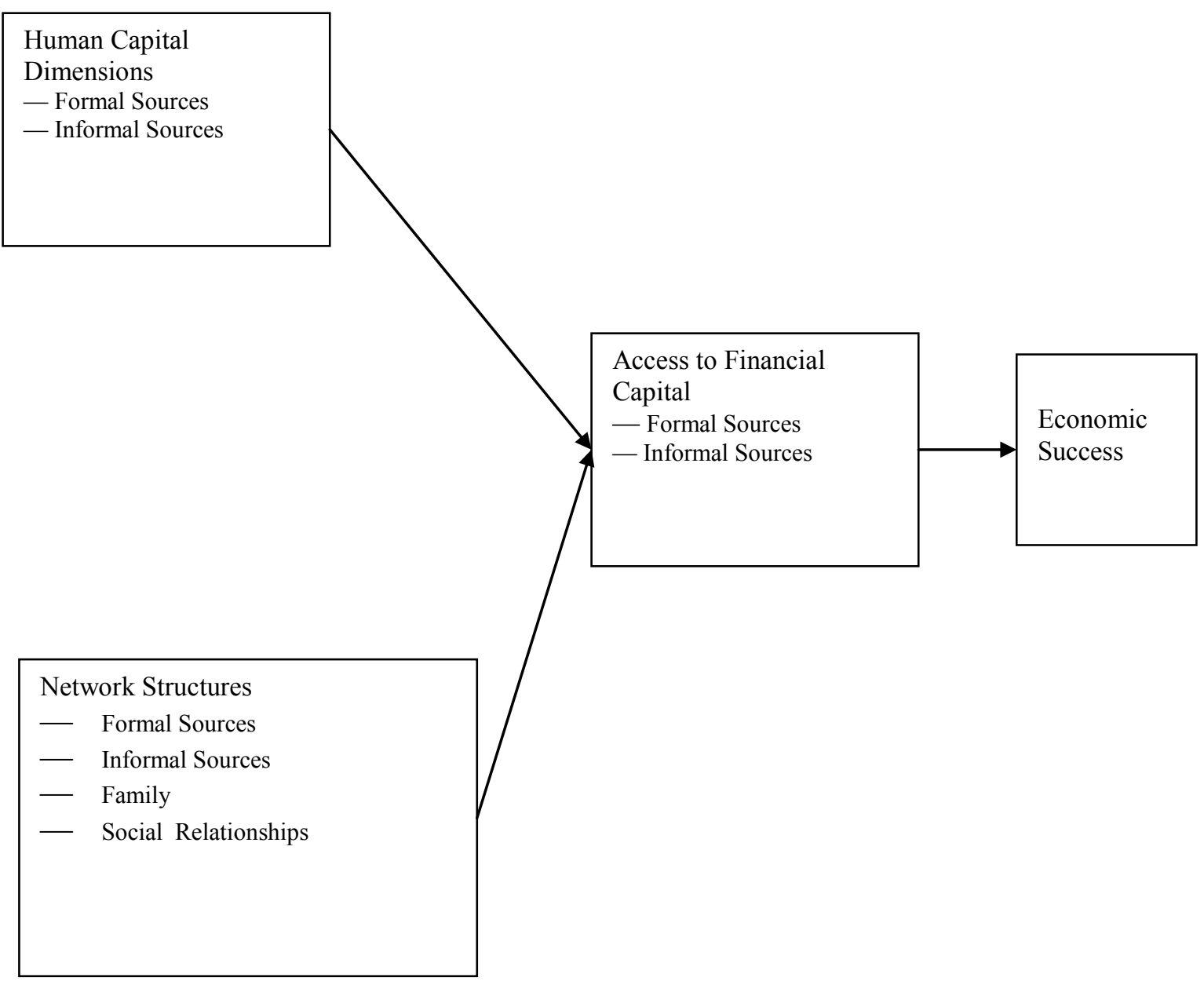


Figure 4: Model of Entrepreneurial Success (Social Entrepreneur)

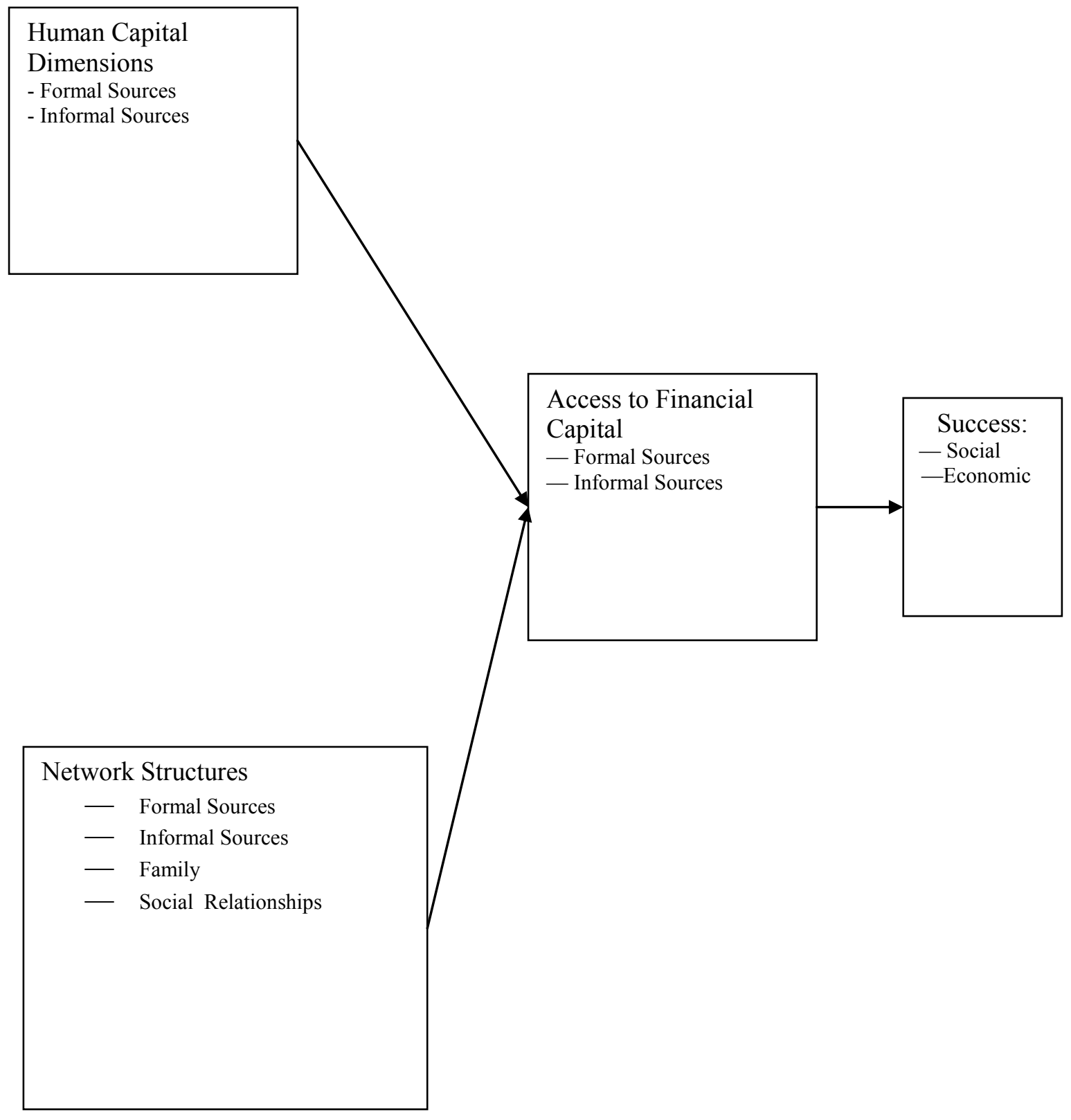




\section{AUTHOR INFORMATION}

Andrea E. Smith-Hunter is an Associate Professor at Siena College in Loudonville, New York. She holds a Ph.D. in Organizational Studies from the University at Albany - State University of New York. Her research interests include entrepreneurship across racial, ethnic, gender and economic lines. She has published journal articles in the Journal of Business and Entrepreneurship, the Journal of International Business and Entrepreneurship, Women in Management Review and the Journal of Business and Economic Research, among others. Her first book, Diversity and Entrepreneurship: Analyzing Successful Women Entrepreneurs, was published in 2003 and her second book, Women Entrepreneurship Across Racial Lines: Issues of Human Capital, Financial Capital and Network Structures was published in 2006 .

\section{REFERENCES}

1. Aldrich H., Reese, P.R. and Dubini, P. 1989. Women on the verge of a breakthrough: Networking among entrepreneurs in the United States and Italy. Entrepreneurship and Regional Development, 1, 339-356.

2. Anderson, A. 2005. Enacted metaphor: The theatricality of the entrepreneurial process. International Small Business Journal, 587-603.

3. Anderson, R., Dana, L, and Dana, T. 2006. Indigenous land rights, entrepreneurship, and economic development in Canada 'opting-in' to the global economy. The Journal of World Business, 45-55.

4. Austin, James E., Stevenson, H. and Jane Wei-Skillern. 2006. Social and commercial entrepreneurship: Same, different or both. Entrepreneurship, Theory and Practice, 30, 1.

5. Backar, T. 2004. Social entrepreneurship: Beyond theory. Philanthropy, 1-3.

6. Bailey, T. and Waldinger, R. 1991. Primary, secondary and enclave labor markets: A training systems approach. American Sociological Review, 56, 432-445.

7. Barendsen, L. and Gardner, H. 2004. Is the social entrepreneur a new type of leader? Joshua Venture Newsletter, 1-7.

8. Bates, T. 1995a. Self-Employment Entry Across Industry Groups. Journal of Business Venturing, 10, 143156.

9. Bates, T. 1990. Entrepreneur Human Capital Inputs and Small Business Longevity. The Review of Economics and Statistics: Volume LXXII, 551-559.

10. Becker, G. 1993. Human capital :a theoretical and empirical analysis, with special reference to education. Chicago : The University of Chicago Press.

11. Beggs, J. J. 1995. The institutional environment: Implications for race and gender inequality in the U.S. labor market. American Sociological Review, 60, 612-633.

12. Begley, T. and Boyd, D. 1987. A comparison of entrepreneurs and managers of small business firms. Journal of Management, 13 (1), 99-108.

13. Bitler, M. P., Robb, A. M., \& Wolken, J. D. 2001. Financial services used by small businesses: Evidence from the 1998 survey of small business finances. Federal Reserve Bulletin, 87, 183-205.

14. Bornstein, D. 2004. How to change the world: Social entrepreneurs and the power of new ideas. Oxford University Press, London, England.

15. Boschee, J. and McClurg, J. 2003. Toward a better understanding of social entrepreneurship: Some important distinctions. http://www.se-alliance.org/better understanding.pdf

16. Boucekkine, R., de la Croix, D., and Licandro, O. 2002. Vintage Human Capital, Demographic Trends, and Endogenous Growth. Journal of Economics, 104, 340-375.

17. Boyd, R. 1996a. Demographic change and entrepreneurial occupations: African Americans in northern cities. The American Journal of Economics and Sociology, 55 (2), 129-144.

18. Breton, A. and Breton, R. 1969. An economic theory of social movements. American Economic Review, 59, 198-205.

19. Bygrave, W. and Hofer, C. 1991. Theorizing about entrepreneurship. Entrepreneurship, Theory and Practice, 16 (2), 13-22.

20. Cable, D. and Shane, S. 1997. A prisoner's dilemma approach to entrepreneur-venture capitalist relationships. The Academy of Management Review, 22 (1) 142-176. 
21. Carland, J.W., Hoy, F., Bolton, W., \& Carland, J. 1984. Differentiating entrepreneurs from small business owners. The Academy of Management Review, 9, 254-259.

22. Choi, T. Y., \& Hong, Y. 2002. Unveiling the structure of supply networks: Case studies in Honda, Acura, and DaimlerChrysler. Journal of Operations Management, 20, 469-493.

23. Christie, M. and Honig, B. 2006. Social entrepreneurship: New research findings. The Journal of World Business, 1-5.

24. Christou, C. 2001. Differential borrowing constraints and investment in human capital. Journal of Macroeconomics, 23, 277-295.

25. Chung, L. and Gibbons, P. 1997. Corporate entrepreneurship: The roles of ideology and social capital. Group \& Organization Management, 22 (1), 10-31.

26. Cianni, M. \& Romberger, B. 1995. Perceived racial, ethnic, and gender differences in access to development experiences. Group and Organization Management, 20 (4), 440-459.

27. Cooper, A.C. and Dunkelberg, W. 1987. Entrepreneurial research: Old questions, new answers and methodological issues. American Journal of Small Business, 11-23.

28. Coughlin, J., \& Thomas, A. (2002). The Rise of Women Entrepreneurs: People, Processes and Global Trends. Quorum Books, Westport, Connecticut.

29. Dees, G. 2005. Social entrepreneurship: Mobilizing resources for success. The Grantsmanship Center, 1-2.

30. Dees, G. 2001. The meaning of social entrepreneurship. http://www.fuqua.duke.edu/centers/case/documents/dees_sedef.pdf

31. Devine, T. 1994a. Changes in wage-and-salary returns to skill and the recent rise in female selfemployment. Economic Issues For Work and Family, 84 (2) 108-113.

32. Devine, T. 1994b. Characteristics of self-employed women in the United States. Monthly Labor Review, 20-34.

33. Doherty, B. and Thompson, J. 2006. The diverse world of social enterprise: A collection of social enterprise stories. International Journal of Social Economics, 33, 361-364.

34. Donovan, C. 2002. Michael Young: Social entrepreneur. The Sociological Review, 50, 450-453.

35. Drayton, W., Brown, C., and Hillhouse, K. 2006. Integrating social entrepreneurs into the "health for all" formula. Bulletin of World Health Organization, page 591.

36. Easter, G. M. 1996. Personal Networks and Postrevolutionary State Building: Soviet Russia Reexamined. World Politics, 48, 551-578.

37. Ekwensi, O. 2004. The sweet taste of success. African Business, 1-2.

38. Evans, D. and Leighton, L. 1989. Some empirical aspects of entrepreneurship. The American Economic Review, 519-535.

39. Farkas, George, England, Paula, Vicknair, Keven, Kilbourne, Barbara Stanek. 1997. Cognitive Skill, Skill Demands of Jobs, and Earnings among Young European American, African American, and Mexican American Workers. Social Forces, 75, 3.

40. Feagin, J. and Imani, N. 1994. Racial barriers to African American entrepreneurship: An exploratory study. Social Problems, 41 (4), 562-585.

41. Finnerty, J. and Krzystofik. A. 1986. Barriers to Small Business Formation. Journal of Small Business Management, 50-58.

42. Fratoe, F. 1986. A sociological analysis of minority business. The Review of Black Political Economy, 15, 5-29.

43. Fukuyama, F. 2002. Social Capital and Development: The Coming Agenda. SAIS Review, 22 , 23-37.

44. Gartner, W. 1985. A conceptual framework for describing the phenomenon of new venture creation. The Academy of Management Review, 10 (4), 696-706.

45. Gartner, W. 1989. Some Suggestions for Research on Entrepreneurial Traits and Characteristics. Entrepreneurship Theory and Practice, 26-37.

46. Gartner, W. and Bhat, S. 2000. Environmental and ownership characteristics of small businesses and their impact on developments. Journal of Small Business Management, 38 (3), 14-27.

47. Gassenheimer, J., Baucus, D., and Baucus, M. 1996. Cooperative Arrangements among Enterpreneurs : An Analysis of Opportunism and Communication in Franchise Structures. Journal of Business Research, 36, 67-79. 
48. Gimeno J., Folta T., Cooper A. and Woo, C. 1997. Survival of the fittest? Entrepreneurial human capital and the persistence of underperforming firms. Administrative Science Quarterly, 42 (4), 750-783.

49. Godoy R., O’Neill K., McSweeney, K. and Wilkie, D. 2000. Human capital, wealth, property rights, and the adoption of new farm technologies: The Tawahka Indians of Honduras. Human Organization, 59 (2), 222-234.

50. Greller, M. and Stroh, L. 2002. Variations in Human Capital Investment Activity by Age. Journal of Vocational behavior, 61, 109-138.

51. Guaitoli, D. 2000. Human Capital distribution, growth and convergence. Research in Economics, 54, 331350 .

52. Heckman, J. J. 2000. Policies to foster human capital. Research in Economics, 54, 3-56.

53. Hemingway, C. 2005. Personal values as a catalyst for corporate social entrepreneurship.

54. Journal of Business Ethics, 233-249.

55. Hendricks, L. 2001. How Do Taxes Affect Human Capital? The Role of Intergenerational Mobility. Review of Economic Dynamics, 4, 695-735.

56. Henry, S. 2002. Women Fighting For Venture Capital; Study Cites Entrepreneur Networks. The Washington Post, Feb. 13, E5.

57. Hogan, J. M. 2001. Social Capital: potential in family social sciences. Journal of Socio-Economics, 30, $151-155$.

58. Hyden G. 2001. The social capital crash in the periphery. Journal of Socio-Economics, 30, $161-163$.

59. Jain, V. 2004. Not so starving artists. Standard Social Innovation Review, 66-67.

60. Johnson, R. 1963. Occupational type and traditional family ideology. Child Development, 34, 509-512.

61. Kazemipur, A. and Halli, S. 2001 The changing color of poverty in Canada. The Canadian Review of Sociology and Anthropology, 38 (2), 217-239.

62. King, P. and Roberts, N. 1992. An Investigation into the personality profile of policy entrepreneurs. Public Productivity and Management Review, 16, 173-190.

63. Korosec, R. and Berman, E. 2006. Municipal support for social entrepreneurship. Public Administration Review, 446-460.

64. Lasprogata, G. and Cotten, M. 2003. Contemplating enterprise: The business and legal challenges of social entrepreneurship. American Business Law Journal, 41, 68-113.

65. Leibell, D., Daniels, D., and Rickershauser, J. 2006. Foundations as entrepreneurs. Trust and Estates, 1823.

66. Linklaters, 2006. Fostering social entrepreneurship: Legal, regulatory and tax barriers, a comparative study. Recommendations for governments in Brazil, Germany, India, Portland, The United Kingdom and the United States. Presented at the World Economic Forum in Davos.

67. Low, M.B. and Macmillan, I.C. 1988. Entrepreneurship: past research and future challenges. Journal of Management, 14 (2), 139-161.

68. Lucas, Jeffrey W, Younys, Wesley C, Lovaglia, Michael J, and Markovsky, Barry. 2001. Lines of power in exchange networks. Social Forces, 80 (1), 185-214.

69. Mair, J. and Marti, I. 2006. Social entrepreneurship research: A source of explanation, prediction and delight. The Journal of World Business, 36-43.

70. Mier, R. and Giloth, R. 1986. Hispanic employment opportunities: A case of internal labor markets and weak-tied social networks. Social Science Quarterly, 66 (2), 296-309.

71. Mintrom, M. 1997a. The state-local nexus in policy innovation diffusion: The case of school choice. Publius, 27, 41-59.

72. Mintrom, M. 1997b. Policy entrepreneurs and the diffusion of innovation. American Journal of Political Science, 41, 738-770.

73. Mizrahi, Y. 1994. Rebels without a cause? The politics of entrepreneurs in Chihuahua. Journal of Latin American Studies, 26, 137-158.

74. Molm, L. D., Peterson, G., \& Takahashi, N. 2001. The Value of Exchange. Social Forces, 80, 159-184.

75. Munday, B. 2004. CA's Who Cares? CA Magazine, 136, 20-27.

76. Nafziger, E. Wayne. 1977. Entrepreneurship, social mobility and income redistribution in South India. The American Economic Review, 67, 76-80.

77. Ohare, W.O. and Suggs, R. 1986. Embattled black businesses. American Demographics, April, 27-49. 
78. Ong, P. 1981. Factors influencing the size of the black business community., 11, 313-319.

79. Osborne, D. 2001. Valley legend's biggest road show ever. Inc. 23, 83-88.

80. Peberdy, S. and Rogerson, C. 2000. Transnationalism and Non-South African Entrepreneurs in South Africa's small, medium and micro-enterprise (SMME) economy. Canadian Journal of African Studies, 34 (1), 20-40.

81. Pendakur, K., \& Pendakur, R. 2002. Language as both human capital and ethnicity. The International Migration Review, 36, 147-177.

82. Peredo, A. and McLean, M. 2006. Social entrepreneurship: A critical review of the concept. The Journal of World Business, 56-65.

83. Putnam, Robert D.1995.Bowling Alone: America’s Declining Social Capital. Journal of Democracy, 6, 1, 65-78.

84. Raymo, J. M., \& Xie, Y. 2000. Income of the Urban Elderly in Postreform China: Political Capital, Human Capital, and the State. Social Science, 29, 1-24.

85. Roberts, N. and King, P. 1991. Policy Entrepreneurs: Their Activity Structure and Function in the Policy Process. Journal of Public Administration Research and Theory, 1, 147-175.

86. Roper, J. and Cheney, G. 2005. Leadership, learning and human resource management: The meanings of social entrepreneurship today. Corporate Governance, 5, 95-104.

87. Sagawa, S. and Segal, E. 2000. Common interest, common good: Creating value through business and social sector partnerships. California Management Review, 42, 105-122.

88. Sanders, J. M., \& Nee, V. 1996. Immigrant self-employment: The family as social capital and the value of human capital. American Sociological Review, 61, 231-249.

89. Schneider, M. and Teske, P. 1992. Toward a Theory of the Political Entrepreneur: Evidence from Local Government. The American Political Science Review, 86, 737-747.

90. Schwab, 2006. Schwab Foundation for social entrepreneurship: 5 year evaluation report, 2000-2005.

91. Seelos, C. and Mair, J. 2005. Social entrepreneurship: Creating new business models to serve the poor. Business Horizons, 241-246.

92. Sharir, M. and Lerner, M. 2006. Gauging the success of social ventures initiated by individual social entrepreneurs. The Journal of World Business, 6-20.

93. Shaver, K. and Scott, L. 1991. Person, Process, Choice: The Psychology of New Venture Creation. Entrepreneurship Theory and Practice, 16 (2), 23-46.

94. Shen, Hsia-Hua. 2003. The New Entrepreneurs of Europe and Asia: Patterns of Business Development in Russia, Eastern Europe and China. Contemporary Sociology, 32, 320-322.

95. Singer, T. 2001. Can business still save the world? Inc. 23, 60-71.

96. Stearns, T. and Hills, G. 1996. Entrepreneurship and new firm development: A definitional introduction. Journal of Business Research, 36 (1), 1-5.

97. Terpstra, D.E. and Olson, P. 1993. Entrepreneurial start-up and growth: A classification of problems. Entrepreneurship Theory and Practice, Spring, 5-20.

98. Thompson, J., Alvy, G., and Lees, A. 2000. Social entrepreneurship: A new look at the people and the potential. Management Decision, 38, page 328.

99. Thompson, J. 2002. The world of the social entrepreneur. The International Journal of Public Sector Management, 15, 412-430.

100. Van Auken, H. and Horton, H. 1994. Financing patterns of minority-owned small business. Journal of Small Business Strategy, 31-43.

101. Waddock, S. and Post, J. 1991. Social entrepreneurs and catalytic change. Public Administration Review, 51, 393-400.

102. Weerawardena, J. and Mort, G. 2006. Investigating social entrepreneurship: A multidimensional model. The Journal of World Business, 21-35.

103. Wilkinson, Ian and Young, Louise. 2002. On cooperating: Firms, relations, and networks. Journal of Business Research, 2, 123-132.

104. Winfield, I. 2005. Fostering Social entrepreneurship through liberal learning in the social science. Peer Review, 7, 15-17. 
NOTES 